\title{
PENINGKATAN KEMAMPUAN BERFIKIR PESERTA DIDIK KELAS XI A5 SMA NEGERI 1 PEKANBARU MELALUI PENERAPAN MODEL PROBLEM- BASED LEARNING
}

\author{
Betty Holiwarni * 1, Herdini Herdini 1, Agustina Agustina * 2
}

1 Program Studi Pendidikan Kimia, FKIP Universitas Riau, Kampus Binawidya KM 12,5, Pekanbaru 28293, Riau, Indonesia

2 SMAN 1 Pekanbaru, Riau, Indonesia

\begin{tabular}{l}
\hline \multicolumn{1}{c}{ Informasi Artikel } \\
\hline Sejarah Artikel: \\
Diterima: 26-07-2019 \\
Disetujui : 6-07-2020 \\
Dipublikasikan: 20-07-2020 \\
\hline Keywords: \\
Student's Worksheets, \\
Problem Based Learning, \\
Thinking Ability, \\
Learning Ability. \\
\hline
\end{tabular}

\section{A b s t r a k}

Penelitian ini bertujuan untuk meningkatkan kemampuan berfikir peserta didik kelas XI A5 SMA N 1 Pekanbaru melalui Penelitian Tindakan Kelas. Perbaikan pembelajaran dilaksanakan melalui Penerapan Model Problem Based Learning pada mata pelajaran kimia materi termokimia. Data kemampuan berfikir diperoleh dari penilaian terhadap kategori pertanyaan dan jawaban spontan menggunakan lembar observasi dan Lembar Kerja Peserta didik (LKPD) serta penguasaan konsep menggunakan tes tertulis bentuk soal essay dan penilaian terhadap LKPD. Hasil penelitian menunjukkan peningkatan kategori pertanyaan dan jawaban yang diajukan peserta didik secara spontan yaitu $\mathrm{C}_{3}(+37,5 \%), \mathrm{C}_{4}(+3,3 \%), \mathrm{C}_{5}(+4,7 \%)$, dan $\mathrm{C}_{6}(+11,1 \%)$, dan menurun untuk $\mathrm{C}_{1}(-34 \%)$ dan $\mathrm{C}_{2}(-11,1 \%)$ dan penilaian melalui LKPD peningkatan terjadi pada $\mathrm{C}_{3}(+21,7 \%), \mathrm{C}_{4}$ $(+2,9 \%), \mathrm{C}_{5}(+7,1 \%)$, dan $\mathrm{C}_{6}(+12,8 \%)$, dan menurun untuk $\mathrm{C}_{1}(-44,3 \%)$ dan $\mathrm{C}_{2}(-18,6 \%)$. Peningkatan pada penguasaan konsep untuk penilaian melalui tes tertulis yaitu kategori baik sekali $(+11,4 \%)$, baik $(+14,3 \%)$ dan menurun untuk kategori cukup $(-2,9 \%)$, kurang $(-9,6 \%)$ dan kurang sekali $(-11,4 \%)$ dan penilaian melalui LKPD yaitu meningkat untuk kategori baik sekali $(+8,6 \%)$, baik $(+5,7 \%)$ dan menurun untuk kategori cukup ($11,4 \%)$, kurang $(-2,8 \%)$ serta tidak ada penguasaan konsep peserta didik kategori kurang sekali selama pembelajaran melalui penilaian LKPD. Hasil penelitian menunjukkan penerapan PBL dapat meningkatkan keterampilan berfikir peserta didik.
A b s t r a c t
This research purpose is to assess and improve the thinking abilities of 11 grader of SMAN 1 Pekanbaru by using classroom-based action research. Problem-Based Learning Model has been used in thermochemistry section of Chemistry subject to improve learning ability. The thinking and learning ability data are directly collected from students' worksheets (SWs) and observation of students' spontaneous questions, the quality of that questions and also the quality of the answers when the teaching activities were held. The subject comprehension data are carefully taken from essay written test and SWs assessment. The results showed the improvement of students' spontaneous questions and answers in $C_{3}(+37,5 \%), C_{4}(+3,3 \%)$, $C_{5}(+4,7 \%), C_{6}(+11,1 \%)$, but in $C_{1}(-34 \%)$ and $C_{2}(-11,1 \%)$ were found. In 
SWs, the improvements are showed in $C_{3}(+21,7 \%), C_{4}(+2,9 \%), C_{5}$ $(+7,1 \%), C_{6}(+12,8 \%)$, and degression in $C_{1}(-44,3 \%)$ and $C_{2}(-18,6 \%)$. In subject comprehension, for essay written test, improvements are showed in excellent $(+11,4 \%)$ and very good $(+14,3 \%)$ cetegories, whereas degression is showed in good (-2,9\%), fine (-9,6\%) and bad $(-11,4 \%)$ categories. In subject comprehension, for SWs assessment, improvements are showed in excellent $(+8,6 \%)$ and very good $(+5,7 \%)$ categories, whereas degression in good $(-11,4 \%)$, fine $(-2,8 \%)$ categories. Fortunately there is no student in bad categories. The results showed that problembased learning model can improve learning and thinking abilities of the students.

(C) 2020 JPK UNRI. All rights reserved

*Alamat korespondensi:

e-mail: warniholy@gmail.com (B.H) dan agustina100867@gmail.com (A.A)

No. Telf: +6282174841191

\section{PENDAHULUAN}

Pembelajaran berpusat pada peserta didik seperti yang diamanatkan pada Kurikulum 2013 sebetulnya bukan sesuatu yang baru, tetapi sudah dicanangkan mulai dari Kurikulum 1975 dengan istilah CBSA (cara belajar siswa aktif). Meskipun sudah berlangsung selama 45 tahun tetapi harapan itu masih jauh dari kenyataan, konsep tersebut hanya tersimpan di meja kepala sekolah dan guru sebagai naskah dokumen kurikulum.

Guru merupakan salah satu faktor penentu dalam mensukseskan implementasi kurikulum (Mulyasa, 2015) karena kegiatan pembelajaran yang terjadi di kelas sesuai dengan apa yang ada dipikiran/dirancangan guru (yang telah dituangkan dalam rencana pelaksanaan pembelajaran/RPP). Oleh karena itu, perubahan kurikulum harus ditunjang dengan guru yang betul-betul menguasai isi dan substansi kirikulum. Maka pada rasional pengembangan Kurikulum 2013, salah satu faktor yang perlu disempurnakan adalah pola pikir (Kemendikbud, 2015).

Kebiasaan/pikiran guru yang merasa belum mengajar kalau belum menjelaskan secara rinci dan tuntas materi pelajaran yang harus dikuasai peserta didik harus diubah, kegiatan peserta didik aktif mencari harus diutamakan karena akan meningkatkan pengetahuan, keterampilan, dan sikap yang diperlukan untuk hidup mandiri di masyarakat, berbangsa dan bernegara.

Pada tahun ajaran 2018/2019 FKIP Universitas Riau mendapat kesempatan melaksanakan program Penugasan Dosen Di Sekolah (PDS) di beberapa sekolah di Kota Pekanbaru. PDS merupakan program nasional dari Kemenristek untuk menciptakan pembelajaran yang bermutu di sekolah dasa $\mathrm{r}$ dan menengah. Ada dua kegiatan yang dilakukan yaitu mengajar dan melakukan penelitian tindakan kelas. Dosen mengajar di kelas bertujuan untuk mengetahui kondisi dan dinamika pembelajaran yang sebenarnya di sekolah untuk mempersiapkan calon guru yang dibutuhkan di lapangan. Manfaat PTK bagi guru untuk meningkatkan kualitas pembelajaran di kelas dan profesionalisme sedangkan bagi dosen untuk publikasi ilmiah dan membantu memperbaiki pembelajaran di kelas sebagai pengalaman nyata untuk bahan perkuliahan.

SMAN 1 Pekanbaru merupakan sekolah tertua yang didirikan di Kota Pekanbaru, merupakan sekolah rujukan nasional untuk tingkat propinsi Riau mulai tahun ajaran 2016/2017 sampai sekarang. Pada tahun ajaran 2018/2019 mendapat kesempatan melaksanakan program PDS untuk pelajaran kimia. Dosen dan guru mitra secara kolaboratif terlibat dalam perencanaan pembelajaran, pelaksanaan pembelajaran, dan evaluasi hasil dan proses pembelajaran. Sebelum kegiatan dilaksanakan terlebih dahulu dilakukan observasi di kelas saat guru mitra melaksanakan pembelajaran untuk mendapatkan informasi tentang suasana belajar dan kondisi peserta didik.

Hasil observasi dan diskusi dengan guru mitra ada berapa permasalahan yang dihadapi pada pembelajaran kimia di sekolah ini diantaranya: 1) pembelajaran kimia masih cenderung bersifat 
content based; 2) lebih sering dilakukan dengan ceramah dan tugas yang diberikan hanya menyelesaikan soal-soal yang ada dibuku paket; 3) tidak pernah melakukan praktikum atau demonstrasi. Akibatnya aktivitas belajar rendah, peserta didik kurang aktif dalam mencari pengetahuan hanya menunggu penjelasan materi oleh guru dan kemampuan berpikir juga masih rendah, salah satu indikatornya adalah jarang mangajukan pertanyaan maupun menjawab pertanyaan guru atau temannya, pertanyaan-pertanyaan yang diajukan hanya tentang materi yang kurang/tidak dipahami dari penjelasan guru.

Masalah-masalah yang ditemukan SMAN 1 Pekanbaru di atas cukup kompleks, akan tetapi secara umum dapat ditetapkan menjadi beberapa masalah, yaitu keterlibatan peserta didik dalam mencari pengetahuan sendiri sangat rendah dan proses pembelajaran yang belum berdasarkan filosofi konstruktivisme. Hal ini diduga menyebabkan kemampuan berpikir peserta didik masih rendah, sehingga pada penelitian ini dicoba untuk menyelesaikan masalah rendahnya kemampuan berpikir peserta didik dengan pembelajaran konstruktivistik karena dapat melatih kemampuan bertanya dalam upaya mengembangkan kemampuan berfikir, bernalar, berargumentasi dan pemecahan masalah.

Salah satu model pembelajaran yang didukung oleh teori belajar konstruktivistik adalah model problem based learning (PBL), model ini dirancang supaya peserta didik menemukan pengetahuan melalui proses pemecahkan masalah dengan gaya belajar sendiri dan terampil dalam bekerja sama (Kemendikbud, 2015). Proses pembelajaran dimulai dengan penemuan masalah pada fenomena yang terjadi dalam kehidupan sehari-hari yang menarik perhatian peserta didik dan diakhiri dengan presentasi serta diskusi dari hasil penemuan mereka (Osman \& Kaur, 2014). Kegiatan tersebut melatih keterampilan berpikir kritis terutama aspek merumuskan masalah, melakukan evaluasi, melakukan penalaran dan menyimpulkan, serta mengambil keputusan dan tindakan. Peserta didik dihadapkan pada suatu wacana yang menyangkut fenomena yang nyata mengenai materi yang akan dipelajari kemudian mengidentifikasi atau menganalisis permasalahan, membuat rumusan masalah, mencari dan menggali informasi dari berbagai sumber ataupun melalui praktikum dan mengamati, merumuskan solusi, menentukan solusi terbaik, sampai mempresentasikan hasil diskusi. Penelitian yang telah menerapkan model problem-based learning pada mata pelajaran kimia untuk meningkat hasil belajar pada subjek hukum-hukum dasar kimia (Wasonowati et al 2104) dan meningkat kemampuan berfikir kritis peserta didik pada pokok bahasan kesetimbangan kimia (Astuti et al 2018).

Mengingat kelebihan-kelebihan dari PBL yang telah dijelaskan di atas, maka model PBL digunakan dalam pembelajaran di SMAN I Pekanbaru, kelas XIA5. Model problem based learning tidak selalu menggunakan sarana dan prasarana berharga mahal, akan tetapi alat dan bahan di lingkungan sekolah dan sekitarnya dapat digunakan sebagai penunjang pembelajaran. Apalagi sekarang guru dapat dengan mudah mencari pengganti zat-zat yang tidak tersedia di laboratorium untuk melakukan praktikum dengan browsing di internet diharapkan PBL yang diterapkan melalui penelitian ini dapat meningkatkan keterampilan berpikir peserta didik kelas XI A5 SMAN I Pekanbaru.

\section{METODE PENELITIAN}

Penelitian ini merupakan kolaborasi antara dosen Pendidikan Kimia FKIP Universitas Riau dengan guru kimia SMA N I Pekanbaru melalui penelitian tindakan kelas (classroom based action research). Penelitian ini bahagian dari program PDS yaitu untuk perbaikan dan peningkatan kualitas pembelajaran di sekolah. Peserta didik yang menjadi subyek penelitian adalah kelas XIA5 yang berjumlah 35 orang, terdiri dari 9 orang laki-laki dan 16 orang perempuan. Pelaksanaan penelitian dimulai dari bulan Juli sampai Oktober 2018 dan pelaksanaan tindakan dilakukan pada bulan September sampai Oktober 2018.

\section{Parameter dan Instrumen Penelitian}

Parameter dan instrument kemampuan perfikir pada penelitian ini: 
1. Kategori pertanyaan dan jawaban yang diajukan peserta didik menggunakan lembar observasi dan LKPD

2. Penguasaan konsep peserta didik pada setiap kompetensi dasar menggunakan tes tertulis bentuk soal essay dan penilaian terhadap LKPD.

\section{Prosedur Penelitian}

Ada 4 tahap kegiatan utama yang dilakukan yaitu perencanaan dan pelaksanaan tindakan serta observasi dan refleksi (Kemmis dan Taggart.1992). Bagan dari langkah tersebut seperti Gambar 1.

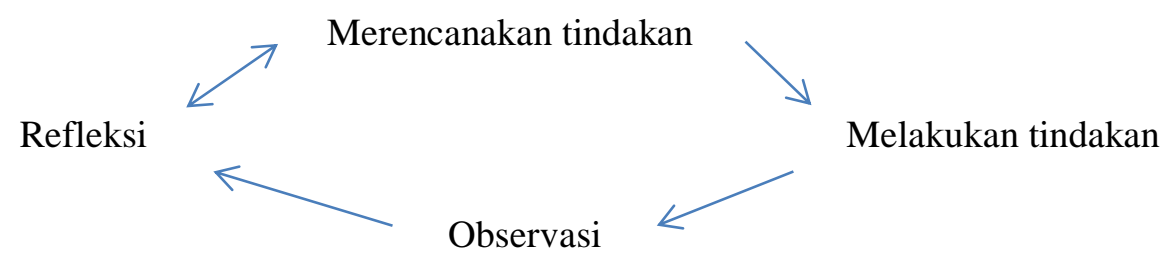

Gambar 1. Prosedur Penelitian Tindakan Kelas

\section{Tahap Perencanaan}

Sebelum pelaksanaan penelitian tindakan kelas dilakukan persiapan-persiapan sebagai berikut.

1. Bersama guru menetapkan kelas, jadwal, materi, jumlah siklus dan pertemuan. Materi yang ditetapkan adalah termokimia karena sesuai dengan jadwal pada program semester di sekolah tersebut. Sesuai silabus ada 2 kompetensi dasar (KD) untuk termokimia dengan alokasi waktunya 16 jam pelajaran maka ditetapkan jumlah siklus yaitu dua, dengan rician KD 3.4 dan 4.4 siklus satu dengan dua pertemuan dan KD 3.5 dan 4.5 siklus dua juga dengan dua pertemuan, masingmasing pertemuan 4 jam pelajaran (4x45 menit).

2. Bersama guru menyusun perangkat pembelajaran (RPP, LKPD, dan lembar penilaian), RPP dan LKPD yang dirancang mengacu pada sintaks model problem based learning, dan lembar penilaian bentuk tes essay untuk mengukur keterampilan berpikir peserta didik. Kemudian menyusun lembar pengamatan yang digunakan untuk mengamati aktivitas peserta titik terutama aktivitas mengajukan dan menjawab pertanyaan selama proses pembelajaran. Pertanyaan dan jawaban yang dikategorikan oleh Anderson \& Krathwol (dalam Muslimin, 2005): $\mathrm{C}_{1}$ (pengingat), $\mathrm{C}_{2}$ (pemahami), $\mathrm{C}_{3}$ (menerapkan), $\mathrm{C}_{4}$ (menganalisis), $\mathrm{C}_{5}$ (mengevaluasi), $\mathrm{C}_{6}$ (menciptakan).

3. Dibantu laboran sekolah, mempersiapkan alat dan bahan praktikum yang diperlukan selama tindakan berlangsung.

\section{TahapPelaksanaan Tindakan}

Kegiatan belajar mengajar pertama dilasanakan di labortorium, dimana peserta didik melakukan praktikum selama 2 jam pelajaran dan selanjutnya di kelas untuk mempresentasikan hasil percobaan dan diskusi. Hal tersebut dilaksanakan karena di laboratorium tidak memungkinkan untuk melaksakan presentasi dan diskusi. Laboratorium yang digunakan adalah laboratorium Biologi karena laboratorium kimia sedang direnovasi. Proses belajar mengajar disesuaikan dengan 5 fase dalam PBL. Pendahuluan (5 menit)

- Peserta didik sudah duduk dalam kelompok yang sudah ditentukan.

- Guru menyampaikan 63okum63met pencapaian kompetensi untuk setiap pertemuan.

- Guru menjelaskan mekanisme pelaksanaan belajar mengajar sesuai dengan langkah-langkah PBL .

Kegiatan Inti ( $2 \times 45$ menit praktikum di laboratorium dan $2 \times 45$ menit presentasi di kelas).

Peserta didik bekerja sesuai dengan petunjuk yang ada dalam LKPD. Langkah-langkah kegiatan di LKPD disusun sesuai dengan lima tahapan pada PBL yaitu: 
- Mengorganisasikan peserta didik pada masalah

Pada halaman pertama LKPD yang telah dibagikan untuk masing-masing peserta didik, terlihat gambar mengenai peristiwa yang dialami atau diamati di kehidupan sehari-hari yang berhubungan dengan materi yang sedang dipelajari dengan tujuan untuk memfokuskan mereka pada masalah.

- Mengorganisasikan peserta didik untuk belajar

Setelah mengamati gambar, mereka diminta mengidentifikasi masalah yang muncul dari pikiran mereka masing-masing. Masalah-masalah tersebut ditulis di kolom yang telah di sediakan di LKPD. Kemudian mereka berdiskusi dalam kelompok untuk memilih masalah yang akan dipecahkan dan ditulis di kolom rumusan masalah. Setelah membaca 64okum64mete dan berdiskusi mereka mengajukan jawaban sementara dari pertanyaan yang telah dirumuskan tadi (berhipotesis).

- Membantu Penyelidikan

Pada tahap ini peserta didik di kelompoknya masing-masing melakukan praktikum untuk memperoleh data untuk menjawab pertanyaan yang telah di ajukan pada rumusan masalah atau membuktikan hipotesis.

- Membimbing dan memfasilitasi peserta didik menyajikan hasil pemecahan masalah.

Mengelompokkan data yang dikumpulkan pada saat praktikum sesuai kategorinya untuk mendapatkan suatu kesatuan dan menganalisis sehingga ditemukan konsep-konsep kimia. Konsepkonsep tersebut dapat digunakan untuk menjawab pertanyaan di awal pembelajaran atau pemecahan masalah. Setelah data diperoleh kemudian masing-masing kelompok membuat bahan untuk presentasi

- Mengevaluasi proses pemecahan masalah

Diakhir kegiatan guru meminta peserta didik melakukan refleksi terhadap keseluruhan kegiatan selama proses pembelajaran. Sehingga ditemukanlah kegiatan-kegiatan yang kurang baik dan tidak menyenangkan yang perlu diperbaiki dan dikurangi serta kegiatan-kegiatan yang baik yang perlu di pertahankan dan ditingkatkan.

\section{Penutup ( 5 menit)}

- Guru menugaskan peserta didik untuk melakukan pengamatan dan mencari informasi lanjutan terkait dengan bahasan yang telah dipelajari agar konsep yang sudah dipelajari menjadi bermakna. Kemudian peserta didik juga diminta mempelajari materi pelajaran untuk pertemuan selanjutnya atau bahan yang akan digunakan pada pertemuan selanjutnya.

- Guru menutup pelajaran dengan salam.

\section{Tahap Observasi}

Selama pembelajaran berlangsung setiap pertemuan dua orang dosen dan dua orang mahasiswa pendidikan kimia yang sedang melaksanakan kegiatan pengenalan lapangan persekolahan (PLP) melakukan pengamatan. Pengamatan yang dilakukan adalah melihat aktivitas peserta didik dalam pembelajaran, terutama dalam mengajukan pertanyaan dan jawaban. Pertanyaan yang diajukan peserta didik dilihat dari jumlah yang bertanya dan kategori pertanyaannya atau menjawab pertanyaan.

\section{Tahap Analisis dan Refleksi}

Segera setelah proses belajar mengajar dilaksanakan pada setiap pertemuan, dilakukanlah analisis data yang telah dikumpulkan oleh observer. Hasilnya dijadikan untuk melakukan perbaikan tindakan pada pertemuan berikutnya.

\section{Analisis Data}

Analisis deskriptif dilakukan terhadap kemampuan berpikir peserta didik. Kemampuan berpikir dinilai dari kategori pertanyaan dan jawaban spontan yang diberikan peserta didik baik saat melaksanakan praktikum maupun saat presentasi dan diskusi yang dicatat oleh observer serta menilai 
pertanyaan dan jawaban yg diajukan pada identifikasi masalah, rumusan masalah dan hipotesis pada LKPD. Sedangkan penguasaan konsep dinilai berdasarkan kuis siklus 1, 2 dan juga dari LKPD.

Tabel 1, Interval dan kategori hasil belajar

\begin{tabular}{ccc}
\hline No & Interval & Kategori \\
\hline 1 & $80-100$ & Baik sekali \\
2 & $70-79$ & Baik \\
3 & $60-69$ & Cukup \\
4 & $50-59$ & Kurang \\
5 & $40-49$ & Kurang sekali \\
\hline
\end{tabular}

\section{HASIL}

Kegiatan belajar mengajar dapat dilaksanakan sesuai dengan tahapan PBL, namun pada awal pembelajaran ditahap merumuskan masalah cukup sulit dikarenakan permasalahan yang dibuat peserta didik saat identifikasi masalah masih banyak yang tidak mengarah ke tujuan percobaan (kategori pertanyaannya masih pada $\mathrm{C}_{1}$ (mengingat) dan $\mathrm{C}_{2}$ (pemahaman) untuk itu guru memberikan membimbing melalui pertanyaan-pertanyaan yang mengarah kepada rumusan masalah yang sesuai dengan tujuan percobaan.

Peserta didik sangat menyukai kegiatan praktikum atau pengamatan langsung. Hampir semua peserta didik bersemangat belajar dan menganggap bahwa pembelajaran sangat menyenangkan karena peristiwa-peristiwa yang mereka temui dalam kehidupan sehari-hari berhubungan dengan materi kimia yang dipelajari di kelas.

Secara umum refleksi siklus 1:

- Perlu diberi latihan cara mengidentifikasi dan merumuskan masalah yaitu melatih cara membuat pertanyaan dan menjawab pertanyaan yang baik, terutama untuk pertanyaan yang memerlukan kemampuan menentukan sudut pandang (mencirikan), membuat keputusan (mengevaluasi) dan menggabungkan unsur-unsur bersama-sama (mencipta). Selama ini pertanyaan yang diajukan guru atau temannya saat diskusi dapat dijawab dengan menanyakan ke google dan mereka tidak perlu berfikir, tapi langsung membaca apa yang tertulis pada gadget tanpa menelaah dan memahami maksudnya.

- Aktivitas peserta didik perlu ditingkatkan pada siklus berikutnya terutama mencari referensi tentang materi pelajaran di internet dengan menjelaskan situs-situs yang 65oku mereka akses, sehingga gadget dapat dimanfaatkan untuk belajar.

Berikut ini adalah beberapa hal yang direncanakan untuk perbaikan di siklus II.

- LKPD dibagikan dua hari sebelum kegiatan pembelajaran dilaksanakan, agar dapat dipelajari terlebih dahulu.

- Lembar pertanyaan yang telah dibuat oleh peserta didik dikumpulkan dan diskor sebelum kegiatan belajar mengajar untuk mengefisienkan waktu belajar dan meningkatkan aktivitas dalam membuat pertanyaan.

\section{Refleksi Siklus II}

Mengidentifikasi masalah, merumuskan masalah dan hipotesis dilakukan sebelum kegiatan belajar mengajar dilaksanakan. Tujuannya adalah untuk melaksanakan PBL sesuai tahapannya dan waktu yang sudah disediakan di kelas. Ketiga tahapan kegiatan tadi sudah dapat terlaksana dengan baik, dan kualitas pertanyaan juga sudah meningkat yang ditandai dengan munculnya pertanyaan yang dapat dikategorikan sebagai pertanyaan analisis, evaluasi, dan mencipta. 
Sama seperti siklus I, peserta didik sangat menyukai kegiatan praktikum atau pengamatan langsung. Praktikum yang dilakukan pada siklus II adalah menghitung perubahan entalpi dengan cara 66okum66meter dan membuktikan hukum Hess. Secara umum, refleksi pada siklus II:

- Setiap langkah kegiatan pembelajaran sudah dilaksanakan secara lebih baik.

- Kualitas pertanyaan dan jawaban sudah mengalami peningkatan tetapi yang mengajukan pertanyaan dan menjawab pertanyaan secara spontan belum merata. Masih ada peserta didik yang masih malu-malu dan ragu-ragu serta kurang percaya diri dalam mengajukan dan menjawab pertanyaan baik terhadap guru maupun teman mereka.

\section{Temuan Penelitian}

Kemampuan berpikir peserta didik meningkat selama kegiatan belajar mengajar berlangsung, hal ini dapat dilihat dari pertanyaan yang diajukan sudah banyak pada kategori aplikasi dan analisis, baik pertanyaan yang diajukan secara spontan maupun pertanyaan yang diajukan pada identifikasi masalah dan rumusan masalah. Pertanyaan yang diajukan secara spontan selama kegiatan belajar mengajar dapat dilihat pada Tabel 2 dan saat identifikasi dan rumusan masalah di LKPD pada Tabel 3.

Tabel 2. Aktivitas Peserta Didik Mengajukan/Menjawab Pertanyaan Secara Spontan

\begin{tabular}{|c|c|c|c|c|c|c|c|c|c|c|c|}
\hline \multirow{3}{*}{$\begin{array}{c}\text { Kategori } \\
\text { Pertanyaan }\end{array}$} & \multicolumn{5}{|c|}{ Siklus 1} & \multicolumn{5}{|c|}{ Siklus 2} & \multirow{3}{*}{$\begin{array}{c}\% \\
\text { Perubahan }\end{array}$} \\
\hline & \multicolumn{2}{|c|}{ Pert. 1} & \multicolumn{2}{|c|}{ Pert. 2} & \multirow{2}{*}{$\begin{array}{l}\text { Rata- } \\
\text { rata }\end{array}$} & \multicolumn{2}{|c|}{ Pert. 1} & \multicolumn{2}{|c|}{ Pert. 2} & \multirow{2}{*}{$\begin{array}{l}\text { Rata- } \\
\text { rata }\end{array}$} & \\
\hline & $f$ & $\%$ & $\mathrm{f}$ & $\%$ & & $f$ & $\%$ & $\mathrm{f}$ & $\%$ & & \\
\hline $\mathrm{C}_{1}$ & 3 & 42,9 & 2 & 25 & 34 & 0 & 0 & 0 & 0 & 0 & -34 \\
\hline $\mathrm{C}_{2}$ & 3 & 42,9 & 2 & 25 & 34 & 2 & 22,2 & 0 & 0 & 11,1 & $-11,1$ \\
\hline $\mathrm{C}_{3}$ & 0 & 0 & 2 & 25 & 12,5 & 4 & 44,4 & 5 & 55,6 & 50 & $+37,5$ \\
\hline $\mathrm{C}_{4}$ & 1 & 14,3 & 1 & 12,5 & 13,4 & 1 & 11,1 & 2 & 22,2 & 16,7 & $+3,3$ \\
\hline $\mathrm{C}_{5}$ & 0 & 0 & 1 & 12,5 & 6,3 & 1 & 11,1 & 1 & 11,1 & 11,1 & $+4,7$ \\
\hline $\mathrm{C}_{6}$ & 0 & 0 & 0 & 0 & 0 & 1 & 11,1 & 1 & 11,1 & 11,1 & $+11,1$ \\
\hline Jumlah & 7 & 100 & 8 & 100 & & 9 & 100 & 9 & 100 & & \\
\hline
\end{tabular}

Tabel 3. Aktivitas Peserta Didik Mengajukan/Menjawab Pertanyaan pada LKPD

\begin{tabular}{|c|c|c|c|c|c|c|c|c|c|c|c|}
\hline \multirow{3}{*}{$\begin{array}{c}\text { Kategori } \\
\text { Pertanyaan }\end{array}$} & \multicolumn{4}{|c|}{ Siklus 1} & \multirow{3}{*}{$\begin{array}{l}\text { Rata- } \\
\text { rata }\end{array}$} & \multicolumn{4}{|c|}{ Siklus 2} & \multirow{3}{*}{$\begin{array}{l}\text { Rata- } \\
\text { rata }\end{array}$} & \multirow{3}{*}{$\begin{array}{c}\% \\
\text { Perubahan }\end{array}$} \\
\hline & \multicolumn{2}{|c|}{ Pert. 1} & \multicolumn{2}{|c|}{ Pert. 2} & & \multicolumn{2}{|c|}{ Pert. 1} & \multicolumn{2}{|c|}{ Pert. 2} & & \\
\hline & $f$ & $\%$ & $\mathrm{f}$ & $\%$ & & $f$ & $\%$ & $\mathrm{f}$ & $\%$ & & \\
\hline $\mathrm{C}_{1}$ & 21 & 60 & 10 & 28,6 & 44,3 & 0 & 0 & 0 & 0 & 0 & $-44,3$ \\
\hline $\mathrm{C}_{2}$ & 11 & 31,4 & 10 & 28,6 & 30 & 6 & 17,1 & 2 & 5,7 & 11,4 & $-18,6$ \\
\hline $\mathrm{C}_{3}$ & 2 & 5,7 & 8 & 22,9 & 14 & 15 & 42,9 & 10 & 28,6 & 35,7 & $+21,7$ \\
\hline $\mathrm{C}_{4}$ & 1 & 2,9 & 4 & 11,4 & 7,2 & 6 & 17,1 & 8 & 22,9 & 20 & $+2,9$ \\
\hline $\mathrm{C}_{5}$ & 0 & 0 & 2 & 5,7 & 2,9 & 4 & 11,4 & 9 & 25,7 & 18,5 & $+7,1$ \\
\hline $\mathrm{C}_{6}$ & 0 & 0 & 1 & 2,9 & 1,5 & 4 & 11,4 & 6 & 17,1 & 14,3 & $+12,8$ \\
\hline Jumlah & 35 & 100 & 35 & 100 & & 35 & 100 & 35 & 100 & & \\
\hline
\end{tabular}

Pertanyaan dan jawaban yang banyak diajukan peserta didik secara spontan pada pertemuan 1 berada pada kategori $\mathrm{C}_{1}$ (mengingat) dan $\mathrm{C}_{2}$ (memahami) serta berkurang pada pertemuan 2 dan 3 , bahkan pada pertemuan 4 tak ada lagi pertanyaan dan jawaban pada kategori tersebut. Pertanyaan dan jawaban sudah meningkat menjadi kategori $\mathrm{C}_{3}$ (memahami) dan $\mathrm{C}_{4}$ (menerapkan), bahkan sudah ada pertanyaan pada kategori $\mathrm{C}_{5}$ (mengevaluasi) dan $\mathrm{C}_{6}$ (menciptakan). Sedangkan pertanyaan dan jawaban yang diajukan pada LKPD sampai pertemuan 4 atau sampai berakhirnya kegiatan PTK masih ada kategori $\mathrm{C}_{1}$ (mengingat) dan $\mathrm{C}_{2}$ (memahami) tetapi sudah berkurang pada pertemuan berikutnya. 
Sama dengan pertanyaan dan jawaban yang diajukan secara spontan, pada LKPD kategori pertanyaan dan jawaban juga meningkat menjadi kategori $\mathrm{C}_{3}$ (memahami) dan $\mathrm{C}_{4}$ (menerapkan), bahkan sudah ada pertanyaan pada kategori $\mathrm{C}_{5}$ (mengevaluasi) dan $\mathrm{C}_{6}$ (menciptakan).

Pada akhir siklus 1 dan 2 diadakan post-test untuk melihat penguasaan konsep. Post-test dilaksanakan melalui tes tertulis bentuk soal essay dan hasilnya dapat dilihat pada Tabel 4, sedangkan penguasaan konsep melalui penilaian LKPD pada Tabel 5.

Tabel 4. Persentase Penguasaan Konsep Peserta Didik Melalui Tes Tertulis

\begin{tabular}{|c|c|c|c|c|c|c|}
\hline \multirow{3}{*}{ Interval } & \multirow{3}{*}{ Kategori } & \multicolumn{4}{|c|}{ Siklus } & \multirow{3}{*}{$\%$ Perubahan } \\
\hline & & \multicolumn{2}{|c|}{1} & \multicolumn{2}{|c|}{2} & \\
\hline & & $\mathrm{f}$ & $\%$ & $f$ & $\%$ & \\
\hline $80-100$ & Baik sekali & 3 & 8,6 & 7 & 20 & $+11,4$ \\
\hline $70-79$ & Baik & 9 & 25,7 & 14 & 40 & $+14,3$ \\
\hline $60-69$ & Cukup & 12 & 34,3 & 11 & 31,4 & $-2,9$ \\
\hline $50-59$ & Kurang & 7 & 20 & 4 & 11,4 & $-9,6$ \\
\hline $40-49$ & Kurang sekali & 4 & 11,4 & 0 & 0 & $-11,4$ \\
\hline \multicolumn{2}{|c|}{ Jumlah } & 35 & 100 & 35 & 100 & \\
\hline
\end{tabular}

Keterangan; + : mengalami kenaikan - : mengalami penurunan

Tabel 5. Persentase Penguasaan Konsep Peserta Didik Melalui LKPD

\begin{tabular}{|c|c|c|c|c|c|c|}
\hline \multirow{3}{*}{ Interval } & \multirow{3}{*}{ Kategori } & \multicolumn{4}{|c|}{ Siklus } & \multirow{3}{*}{$\%$ Perubahan } \\
\hline & & \multicolumn{2}{|c|}{1} & \multicolumn{2}{|c|}{2} & \\
\hline & & $\mathrm{f}$ & $\%$ & $f$ & $\%$ & \\
\hline $80-100$ & Baik sekali & 4 & 11,4 & 7 & 20 & $+8,6$ \\
\hline $70-79$ & Baik & 15 & 42,9 & 17 & 48,6 & $+5,7$ \\
\hline $60-69$ & Cukup & 12 & 34,3 & 8 & 22,9 & $-11,4$ \\
\hline $50-59$ & Kurang & 4 & 11,4 & 3 & 8,6 & $-2,8$ \\
\hline $40-49$ & Kurang sekali & 0 & 0 & 0 & 0 & 0 \\
\hline \multicolumn{2}{|c|}{ Jumlah } & 35 & 100 & 35 & 100 & \\
\hline
\end{tabular}

Terjadi peningkatan jumlah peserta didik dengan kategori penguasaan konsep baik dan baik sekali serta menurun untuk kategori cukup, kurang dan kurang sekali, bahkan dari awal sampai akhir pembelajaran tidak ada peserta didik dengan penguasaan konsep berada pada kategori kurang sekali untuk penilaian melalui LKPD.

\section{PEMBAHASAN}

Keterampilan berfikir peserta didik meningkat dengan penerapan model problem based learning pada mata pelajaran kimia SMA kelas XI A5 materi pokok termokimia. Hal ini terlihat dari meningkatnya kategori pertanyaan dan jawaban yang diajukan peserta didik secara spontan maupun melalui LKPD, begitu juga penguasaan konsep baik melalui test maupun LKPD juga meningkat. Peserta didik telah mulai memahami bagaimana cara membuat pertanyaan yang jawabannya bukan hanya "ya" atau "tidak".

Peningkatan kategori pertanyaan dan jawaban yang diajukan peserta didik secara spontan yaitu $\mathrm{C}_{3}(+37,5 \%), \mathrm{C}_{4}(+3,3 \%), \mathrm{C}_{5}(+4,7 \%)$, dan $\mathrm{C}_{6}(+11,1 \%)$, dan menurun untuk $\mathrm{C}_{1}(-34 \%)$ dan $\mathrm{C}_{2}$ $(-11,1 \%)$. Untuk penilaian melalui LKPD peningkatan terjadi pada $\mathrm{C}_{3}(+21,7 \%), \mathrm{C}_{4}(+2,9 \%), \mathrm{C}_{5}$ $(+7,1 \%)$, dan $\mathrm{C}_{6}(+12,8 \%)$, dan menurun untuk $\mathrm{C}_{1}(-44,3 \%)$ dan $\mathrm{C}_{2}(-18,6 \%)$. Hal ini sejalan dengan pendapat Sumarmi (2012) yang menyatakan pembelajaran berbasis masalah membantu mengembangkan keterampilan memberikan alasan/jawaban terhadap solusi suatu masalah". Meskipun 
pada pertemuan 1 ada pertanyaan dan jawaban kategori $\mathrm{C}_{4}$ hal ini disebabkan karena di kelas XI $\mathrm{A}_{5}$ ini ada dua peserta didik yang selalu ikut kegiatan "Debat" mulai dari kelas X baik pertandingan ditingkat propinsi maupun tingkat nasional, sehingga pertanyaan dan jawaban yang selalu diajukan sudah masuk kategori $\mathrm{C}_{4}$ dan $\mathrm{C}_{5}$ dan saat berbicara mereka sangat bersemangat dan penuh percaya diri karena mereka sudah terlatih.

Peningkatan juga terjadi pada penguasaan konsep materi termokimia, untuk penilaian melalui tes tertulis yaitu kategori baik sekali $(+11,4 \%)$, baik $(+14,3 \%)$ dan menurun untuk kategori cukup ($2,9 \%)$, kurang $(-9,6 \%)$ dan kurang sekali $(-11,4 \%)$ bahkan pada siklus 2 tidak ada penguasaan konsep peserta didik pada kategori kurang sekali. Begitu juga untuk penilaian melalui LKPD yaitu meningkat untuk kategori baik sekali $(+8,6 \%)$, baik $(+5,7 \%)$ dan menurun untuk kategori cukup $(-11,4 \%)$, kurang $(-2,8 \%)$ serta tidak ada penguasaan konsep peserta didik kategori kurang sekali selama pembelajaran melalui penilaian LKPD. Hasil ini sejalan dengan penelitian Iqbal dkk (2016) bahwa problem based learning dapat meningkatkan pemahaman peserta didik dan termotivasi untuk melakukan penyelidikan baik secara individu maupun kelompok. Widyatiningtyas dkk (2015) juga menemukan bahwa model problem based learning memberikan pengaruh terhadap keterampilan berpikir kritis peserta didik. Keterampilan berpikir kritis dioptimalkan melalui proses kerja kelompok, peserta didik dapat berbagi/bertukar ide atau informasi sehingga menambah pengalaman belajar mereka.

Peningkatan keterampilan berpikir peserta didik menunjukkan adanya perubahan yang positif dalam pembelajaran, mengurangi dominasi guru dalam proses pembelajaran, guru hanya sebagai fasilitator dan motivator. Tahap-tahap pembelajaran lebih banyak dilakukan oleh peserta didik yang telah dituangkan dalam LKPD. Peserta didik selalu diupayakan bekerja secara mandiri maupun kelompok untuk menemukan konsep yang harus mereka pelajari. Pada model problem based learning pembelajaran teacher-centered dapat diminimalkan dan student-centered dapat ditingkatkan .

\section{KESIMPULAN}

1. Penerapan model problem based learning pada pembelajaran kimia materi pokok termodinamika berkontribusi pada kategori pertanyaan dan jawaban serta penguasaan konsep peserta didik yang akhirnya peningkatan keterampilan berfikir peserta didik.

2. Program PDS untuk meningkatkan kualitas pembelajaran melalui penelitian tindakan kelas telah memberikan kontribusi terhadap peningkatan kemampuan berfikir dan penguasaan konsep peserta didik. Bagi guru program ini sangat membantu merealisasikan tuntutan kurikulum terutama pembelajaran yang berpusat pada peserta didik dan bagi dosen membantu memperbaiki pembelajaran di kelas sebagai pengalaman nyata untuk bahan perkuliahan.

\section{DAFTAR PUSTAKA}

Astuti, S., Danial, M., Anwar. M. 2018. Pengembangan lkpd berbasis pbl (problem based learning) untuk meningkatkan keterampilan berpikir kritis peserta didik pada materi kesetimbangan kimia. Chemistry Education Review. 1(2): 90-114

Caesar, M.I.M., Jawawi, R., Matzin, R., Shahrill, M., Jaidin, J. H., Mundia, L. 2016. The Benefit of Adopting a Problem-Based Learning Approach on Students' Learning Developments in Secondary Geography Lessons. International Education Studies. 9(2);51-65

Kemdikbud. 2015. Materi Pelatihan Implementasi Kurikulum 2013 Mata Pelajaran Kimia. Jakarta.

Kemmis, S. M. Taggart, R. 1992.The Action Research Planner. Victoria: Deaken University.

Mulyasa, E. 2015. Guru dalam Implementasi Kurikulum 2013. Bandung: PT Remaja Rosdakarya.

Muslimin.I. (2005). Asesmen Berkelanjutan. Unesa University Press. Surabaya.

Osman, K., \& Kaur, S. J. 2014. Evaluating Biology Achievement Scores in an ICT Integrated PBL Environment. Eurasia Journal of Mathematics, Science \& Technology Education, 10 (3), 185-194. 
Sumarmi. 2012. Model Model Pembelajaran Geografi. Aditya Media Publishing: Yogyakarta

Wasonowati, R.R.T., Redjeki, T., Ariani, S.R.D. 2014. Penerapan model problem based learning (pbl) pada pembelajaran hukum - hukum dasar kimia ditinjau dari aktivitas dan hasil belajar siswa kelas x ipa sma negeri 2 surakarta tahun pelajaran 2013/2014. Jurnal Pendidikan Kimia. 3(3 ); $66-75$

Widyatiningtyas, R., Kusumah, Y. S., Sumarmo, Utari., Sabandar, Jozua. 2015. The Impact of Problem-Based Learning Approach to Senior High School Students' Matematics Critical Thinking Ability. IndoMS-JME, 6(2):30-38. 